\title{
Svar på kommentarer til Modern Political Ecological Analysis
}

Tak til Politica for at give plads til denne debat om bogen Modern Political Ecological Analysis. Det glæder mig specielt, at jeg som en af bogens redaktører fär lejlighed til at svare på ovenstående fire mere eller mindre kritiske bidrag.

Læseren vil måske have lagt mærke til, at bidragene ikke handler om bogen i sin helhed, men specielt om de kapitler, som vedrører anvendelse og evaluering af den såkaldte "logitmetode til økologisk inferens". Man kan endda sige, at Ingemar Glans' bidrag egentlig ikke handler om bogen, men om andre udgivelser fra nogle af bogens forfattere, hvor den famøse metode er anvendt. Forklaringen på denne skævhed i bidragene er sikkert, at inferensproblematikken er særligt kontroversiel. Men til læserens orientering skal jeg kort nævne, at redaktørernes formål med bogen er at give et bredt indblik i moderne nordisk politisk-økologisk forskning. Således omhandler ca. halvdelen af bogen ganske omfattende, men mindre kontroversielle, historiske analyser på makroniveau af blandt andet den tidlige udvikling for de socialistiske partier i Norge og Sverige, af mellemkrigstidens finske fascistparti samt af det norske kommunistparti i den første efterkrigstid. ${ }^{1}$

Som ophavsmand til logitmetoden og medansvarlig for de fleste af de omtalte logitanvendelser har jeg dog i denne sammenhæng intet imod at begrænse mig til dette emne.

\section{Kommentarer til Sven Berg}

Om Sven Bergs indlæg vil jeg gerne sige, at det er en beundringsværdig kort og klar fremstilling af det stade, hvorpå den politisk-økologiske forskning befinder sig, specielt hvad angår inferensproblematikken. ECPR-workshoppen i marts 1991 om anvendelse af valgresultater til at analysere vælgeradfærd, der havde inferensproblematikken som hovedemne, bekræftede stort set Bergs fremstilling. Blandt de fire typer af metoder til økologisk inferens, som Berg nævner, var der således også enighed om at give maximum entropi metoden i Johnstons udformning en særstatus, fordi den forudsætter kendskab til det, som de øvrige metoder søger at estimere: nemlig den individuelle sammenhæng på nationalt niveau. For mig er det dog en spændende nyhed, at maximum entropi metoden ifølge Berg skulle have en mere generel anvendelighed.

Ved sammenligning af de øvrige tre metodetyper forstår jeg Berg således, at han som så mange andre er skeptisk over for regressionsmetoden i dens forskellige mere eller mindre sofistikerede udgaver. Derimod lader han en evaluering af Brown og Paynes ACM-metode i forhold til undertegnedes logitmetode være et 
mere åbent spørgsmål. Af mere principielle træk ved disse to metoder fremhæver han imidlertid, at ACM-metoden til forskel fra logitmetoden er en såkaldt "integreret statistisk model «. Her forstår jeg ham således, at man ved ACM-metoden har et velspecificeret tilfældighedselement, og at man faktisk kan teste modellen alene ved hjælp af de økologiske data, mens noget sådant ikke er muligt med logitmetoden. Det sidste er korrekt, men jeg vil nu tillade mig at sætte spørgsmålstegn ved, om en sådan "intern testbarhed " overhovedet er en ønskelig egenskab ved en inferensmetode. Med den forkætrede regressionsmetode kan man jo også foretage den nydeligste "fitning « til økologiske data, uden det af denne grund leder til valid inferens. Jeg synes også, at man med rette kan stille spørgsmålet, om tilfældighedselementet overhovedet har nogen betydning for økologiske data med flere tusinde observationer i hver geografisk enhed.

Jeg har tidligere påpeget, at der er en logisk parallel mellem økologisk inferensteknik og prognoseteknik. Ved begge teknikker er der en "logisk kløft ", ved prognoser mellem fortid og fremtid og ved økologisk inferens mellem økologisk og individuelt niveau, og jeg tror ikke, at man kan "estimere sig over " denne kløft ved hjælp af en "integreret statistisk model «. Man ville for eksempel ikke teste en prognoses validitet alene ved data fra fortiden, og jeg mener tilsvarende ikke, at man kan teste økologisk inferens validitet alene ved data på økologisk niveau. For at komme over den logiske kløft må man opstille antagelser, som ikke kan testes i udgangsmaterialet.

Som en person, der i snart en halv menneskealder har arbejdet med og undervist i statistisk metode, piner det mig, at Berg om min fremgangsmåde til at evaluere inferensestimaters validitet skriver: "Ovanan att handskas med statistiska grundbegrepp lyser igenom «. Han hentyder her til den fremgangsmåde, (som i øvrigt er blevet anvendt af mange andre end mig), at man beregner et afvigelsesindeks mellem en mobilitetstabel estimeret ved økologisk inferens og en mobilitetstabel fra en surveyundersøgelse ved at summere de absolutte (numeriske) forskelle mellem tilsvarende celler i de to mobilitetstabeller; vel at mærke uden at fundere over, hvilken tilfældighedsvariation der er knyttet til indekset. Man mærker her igen fagstatistikerens lyst til at kunne teste for signifikans mv. - uvantheden med at arbejde med populationsdata skinner igennem. Men forstå mig ret - jeg har nu som tidligere haft stort udbytte af samarbejde med fagstatistikere og vil hermed gerne invitere Sven Berg til at deltage i et sådant samarbejde.

Man kunne nok ved en eller anden form for jack-knife teknik generere en samplingfordeling for det nævnte afvigelsesindeks, for eksempel ud fra antagelser om, at de forskellige surveyudvalg var udtaget simpelt tilfældigt, samt at de økologiske række- og søjlemarginaler var multinomialt fordelt. Som jeg ser problemet, er den usikkerhed, som er knyttet til de økologiske estimationer, imidlertid først og fremmest en usikkerhed, som skyldes en eventuel fejlspecificeret model og ikke "sampel "variation i de økologiske data. Endvidere kan der jo også meget vel være systematiske fejl i surveyundersøgelser. Til denne form for usikkerhed kan man kun med vanskelighed knytte en sandsynlighedsfordeling.

Jeg er også skeptisk over for forslaget om at evaluere validiteten ved hjælp af betingede fordelinger. På den måde kommer for eksempel fordelingen af 10 tidli- 
gere kommunistiske stemmer til at indgå med samme vægt som 300 tidligere socialdemokratiske stemmer, hvilket forekommer urimeligt.

En oplagt mulighed, som både Berg og Glans inde på, er at gå ud fra den nulhypotese, at inferensestimatet af mobilitetstabellen er helt uden bias, dvs. er lig med frekvenserne i den population, hvorfra surveystikprøven er taget. Man kan derefter undersøge, om surveyresultaterne udviser signifikante afvigelser for enkelte (Glans) eller grupperede (Berg) celler i mobilitetstabellen. Det er min erfaring, at resultatet af en sådan fremgangsmåde altid er, at man får store signifikante afvigelser - dvs. at hypotesen om manglende bias ved inferensmetoden kan forkastes. Fremgangsmåden er simpelt hen den sikre vej til at forkaste enhver inferensmetode - men spørgsmålet er imidlertid, om det også er en hel "fair « fremgangsmåde. Selv de mest fanatiske inferenstilhængere vil vel ikke påstå, at deres metode er helt uden bias, og der skal faktisk ikke ret megen bias til for at skabe signifikante afvigelser i forhold til surveyresultater. ${ }^{2}$ I realiteten svarer fremgangsmåden til, at man behandler inferensresultatet, som om det kom fra en uendelig stor stikprøve.

Der er efter min mening større behov for at finde en metode til at sammenligne storrelsesordenen af afvigelserne mellem forskellige tabeller end at udvikle en mere eller mindre sofistikeret signifikanstest. ${ }^{3}$ Efter min bedste overbevisning er det førnævnte indeks ikke så dårligt til at vurdere denne størrelsesorden; og af hensyn til statistisk mindede vil jeg gerne tilføje "i det lange løb«, da der naturligvis til indekset er knyttet en variation, som stammer fra diverse stikprøveudtag og varierende bias.

Berg nævner to væsentlige problemer, som er knyttet til logitmetoden. Det ene er spørgsmålet, om det er nødvendigt at udskille homogene politiske regioner, inden for hvilke der foretages separate estimationer. Her siger min erfaring fra anvendelse af metoden i en række lande, at der i reglen ikke er større forskel på et resultat, der er beregnet for landet som helhed (dvs. ved at betrage hele landet som en enkelt region) og et resultat, der er kumuleret fra flere separate regioner. Specielt hvad angår vælgervandringer er resultatet ofte overraskende ensartet mellem separate regioner - endda også selv om der er dårlig overensstemmelse med surveyresultater. ${ }^{4}$ Hvad angår estimation af klassers partivalg er situationen lidt mere speget, fordi der undertiden kan være stærk interaktion mellem region og klassepartivalg (det danske Fremskridtsparti er et godt eksempel). Jeg må desværre rapportere, at det ved anvendelse af klusterteknik for mig ikke har været muligt at finde frem til bedre regioner end dem, som kan dannes ved hjælp af administrative inddelinger ud fra almindeligt kendskab til regionale kontraster.

Det andet og nok mest alvorlige problem, som Berg nævner, er, at resultatet med logitmetoden er følsomt over for valg af referenceparti. Min erfaring siger mig, at de bedste resultater opnås ved at anvende store og relativt "neutrale partier " (såsom sofavælgerne ved partivalg og pensionister ved klassevalg); men for eksempel Kohlsche fortalte ved ECPR-workshoppen, at han ved estimation af vælgervandringer i Tyskland fảr det bedste resultat ved at anvende det parti, som afgiver flest stemmer, som referenceparti på tidspunkt 1 , og det parti, som modtager flest stemmer, som referenceparti på tidspunkt 2. Det allerbedste ville natur- 
ligvis være, hvis man kunne udvikle metoden, så man helt slap for at skulle vælge referenceparti.

Jeg kan i øvrigt rapportere fra ECPR-workshoppen, at stemningen just ikke var euforisk, hvad angår tiltroen til, at man kan opnå valide estimationer ved hjælp af de nævnte teknikker til økologisk inferens. Der var endda mumlen i krogene om, at "Robinson nok ikke er død endnu ". Det var også mit indtryk, at konstruktørerne af ACM-metoden ikke var for begejstret over deres egne resultater, som var præget af instabilitet, og man skal formodentlig ikke forvente, at der kommer en PC-version af deres program.

Heldigvis var der ikke kun "gamle trætte mænd « til stede ved ECPR-workshoppen. Efter min mening var den unge generation blandt andet fint repræsenteret ved den private konsulent Andreas Kohlsche fra München, som tidligere har udviklet sin egen komponentmetode. Han fremlagde i workshoppen resultater fra anvendelsen af en videreudvikling af komponentmetoden, som tydede på meget høj validitet for mobilitetstabeller (Kohlsche, 1991). Et stærkt træk ved den nye metode er, at den indebærer en simultan, iterativ tilpasning af en række tabeller, hvoraf nogle har kendt indhold på individniveau. Ud over at metoden er meget beregningskrævende, er problemerne med Kohlsches metode, at den ikke har nogen klar teoretisk forankring, samt at dens validitet kun er testet mod nationale surveyresultater, som er projiceret ned på nogle mindre byområder i Tyskland. Et yderligere problem er, at metoden kræver tilgang til individsammenhænge, hvilket er muligt i Tyskland, hvor der tilsyneladende findes populationsdata om splitvoting. Sidste nyt fra Kohlsche er, at han har forladt komponentmetoden og i stedet bruger en variant af logitmetoden sammen med den omtalte simultane tilpasning af flere tabeller (personlig kommunikation).

\section{Kommentarer til Mogens N. Pedersen}

Jeg er glad for, at Mogens Pedersens indlæg minder mig om, hvorfor jeg oprindeligt blev interesseret $\mathrm{i}$ inferensproblematikken. Mit udgangspunkt var, at jeg gennem flere år havde arbejdet med økologiske makroanalyser af valgstatistik, dvs. uden at foretage økologisk inferens. Til dette arbejde havde jeg efter min egen opfattelse udviklet vellykkede metoder, som byggede på min gamle statistiklærer Georg Raschs målingsteori, og jeg følte selv, at modellerne havde en indre logik, som var af stor betydning for forståelsen af fænomenet vælgeradfærd.

Lidt mærkeligt var det dog, at modellernes logik tilsyneladende ikke passede særlig godt med den tids opfattelse af, hvilken dynamik der ligger bag vælgernes adfærd. Ved statiske analyser passede det ganske godt med erfaringer fra interviewundersøgelser, at væsentlige dimensioner i vælgernes adfærd på økologisk niveau var faktorer som social klasse, urbanisering og alder; men kiggede man nærmere på dynamikken over tid, ledte Rasch-modellerne til påstande som: "det er ikke vælgerne men partierne, der bevæger sig “ og "vælgerne reagerer oftere på partiernes bevægelser med konsensus end med modsatrettede interesser " (Thomsen, 1972). Dette passede just ikke med de socialpsykologiske teorier om opinionsdannelse gennem personlig påvirkning og teorier om politik som kampen om samfundets værdifordeling. 
Jeg vil ikke trætte med matematiske formler, men man kan faktisk med god tilnærmelse beskrive vælgeradfærden på økologisk niveau med modeller, der har parametre for de geografiske områder, som er konstante over tid, og parametre for partierne, som er uafhængige af områderne (konstante i rum). Partiparametrene er dels et sæt parametre for det enkelte partis sociale profil, dels en parameter for det enkelte partis generelle popularitet, og det er som antydet ovenfor i højere grad den generelle popularitet end den sociale profil, der varierer over tid.

Denne adskillelse mellem på den ene side noget, der karakteriserer områderne uafhængigt af partiernes bevægelser, og på den anden side noget, der karakteriserer partierne uafhængigt af det økologiske niveau, ledte til den tanke, at de økologisk estimerede partiparametre måske også har en realitet på det individuelle vælgerniveau. Lidt populært kan man sige, at hele fidusen ved logitmetoden for økologisk inferens er, at man fastholder de økologiske partiparametre, men i stedet for de økologiske områder indskyder de enkelte vælgere.

Individniveauet "indskydes " ved to meget simple antagelser om forholdet mellem individuelt og økologisk niveau. Den ene antagelse er den såkaldte isomorfipåstand om, at det er de samme sociale dimensioner, der beskriver såvel forskelle mellem områder som mellem individer, samt at dimensionernes relative betydning er den samme på økologisk som individuelt niveau. Den anden antagelse er påstanden om høj variansrate, dvs. at variationen mellem individer er langt større end variationen mellem områder.

Ovenstående redegørelse er et forsøg på at imødekomme Mogens Pedersens efterlysning af en redegørelse for metodens interne logik. Man formulerer simpelthen den samme model på individniveau, som har givet gode resultater på økologisk niveau, og de to niveauer kædes derefter sammen ved hjælp af nogle simple antagelser. Modellerne er måske ikke helt i overensstemmelse med dominerende teorier om vælgeradfærd, men det kunne jo være, at teorierne trængte til revision. Jeg har med glæde konstateret, at Peter Nannestad i sit bog om »Reactive Voting " fra 1989 netop arbejder med en model for vælgeradfærd, som går ud fra, at det er partierne og ikke vælgerne, der bevæger sig. Jeg savner dog stadig allierede for det synspunkt, at valgdynamik oftere er bestemt af konsensusfænomener end af interessemodsætninger. Jeg er således skeptisk over for Nannestads implicitte påstand om, at det er ved ændringer i den sociale profil, at partierne ændrer deres generelle tilslutning.

Hovedkonklusionen fra det meget citerede kapitel 2 om logitmetodens validitet er, at det ikke så meget er den overordnede logitmodel, der er validitetsproblemer med. Det er snarere de to simple antagelser om isomorfi og høj variansrate, der er for simple. Resultaterne tyder på, at der i Danmark er problemer med isomorfiantagelsen og i Sverige med variansrateantagelsen. Heldigvis viser det sig, når man studerer et bestemt land, at afvigelserne mellem inferensresultater og surveyresultater ud over at kunne fortolkes ved hjælp af den generelle logitmodel også har en stærk tendens til at være de samme for alle studerede valgperioder. Dette leder til idéen om at foretage en landespecifik tilpasning af den generelle model.

Denne idé kalder Mogens Pedersen for en farlig tankegang, fordi man herved fratager metoden dens væsentligste kvaliteter, nemlig simpelhed og generalitet. 
Sandt nok, det var netop kombinationen af på den ene side en simpel og generel model og på den andens side meningsfulde resultater, som gjorde, at jeg i sin tid turde publicere metoden. Men man er nok nødt til at leve livet lidt farligt, hvis man skal komme videre. Man kunne også påpege, at det er lidt for vovet at tro, at man kan estimere individuelle sammenhænge ved hjælp af økologiske data uden overhovedet at skele til data på individniveau. Forhåbentlig kan man finde frem til en simpel og generel fremgangsmåde for en landespecifik tilpasning af logitmetoden.

Det er den erfarne forsker, der taler, når Mogens Pedersen kalder vores bog for et "partsindlæg" og kræver uafhængig afprøvning af andre forskere. Jeg er igen tilbøjelig til at give ham ret. Efter min egen mening er samfundforskning netop så wishy-washy, at det ikke er den store kunst at "bevise " næsten hvad som helst, hvis man bare selv kan kontrollere fremstillingen. Man kan endog sige, at forskere, som anvender mit PC-program ECOL til økologisk inferens på egne data, strengt taget ikke ved, om programmet er i overensstemmelse med de skriftlige fremstillinger af metoden.

På denne baggrund kan jeg ikke dy mig for at referere resultatet af en omfattende sammenligning af forskellige inferensmetoder, som blev fremlagt af Fritz Krauss fra det tyske INFAS institut på den føromtalte workshop (Krauss, 1991). Datamaterialet var dels interviewresultater, dels økologiske data vedrørende vælgervandringer fra Bundestagswahl 1987 til 1990 inden for hele det område, der svarer til det tidligere Vesttyskland. Det økologiske materiale var interessant i den forstand, at det dels bestod af resultater fra samtlige valgkredse, dels af en stikprøve af mindre valgsteder. Endvidere havde Krauss selv programmeret Thomsens logitmetode, Kohlsches komponentmetode, Swindels ridge regressionsmetode samt sin egen version af regressionsmetoden. Krauss havde ikke selv sammenfattet forskellene mellem de forskellige estimerede mobilitetstabeller, men bruger jeg mit forskelsindeks på Krauss' tabeller, får man dels det interessante resultat, at økologiske estimationer ved hjælp af valgstedsdata for alle fire metoder ligger markant nærmere ved interviewresultater end økologiske estimationer ved hjælp af valgkredsdata, og dels det for mig ikke mindre interessante resultat, at logitmetoden klarer sig bedst. ${ }^{5}$ Faktisk er forskellen mellem survey- og logitinferens med valgstedsdata nede på et niveau, der svarer til de gunstige resultater fra finske valg.

I relation til Mogens Pedersens efterlysning af logitmetodens afprøvning i flere lande kan jeg melde, at metoden for øjeblikket planlægges afprøvet i UK, USA, Italien, Australien samt Sydkorea.

\section{Kommentarer til Ingemar Glans}

Desværre er det langt fra altid, at logitmetoden giver gunstige resultater. Det kan Ingemar Glans i høj grad tale med om. Med sit omfattende kendskab til interviewresultater har det ikke været noget problem for ham at finde udvalgte eksempler frem, hvor diskrepansen mellem surveyresultater og inferensestimater er markante. Det finder jeg helt i orden - som bekendt er det vigtigere at koncentrere sig om falsificering end om verificering. 
I visse tilfælde er det dog døde heste, Glans pisker på. Ser man for eksempel på hans sammenligning af vælgeradfærd blandt funktionærer og selvstændige i 1971 (et "genoptryk « af Glans, 1989), fremgår det, at der er større overensstemmelse mellem to interviewundersøgeler end mellem inferensestimater og interviewundersøgelser. Rent bortset fra, at forskellen mellem survey og inferens nok er mindre, end den, man ville finde med andre inferensmetoder, vil jeg tillade mig at gøre opmærksom på, at afvigelserne faktisk er i overensstemmelse med, hvad man skulle forvente. Som jeg tidligere har fremhævet (Thomsen, 1987: 96), er der ved økologisk inferens i Danmark en tilbøjeliged til, at urbaniseringsdimensionen har for stor betydning i relation til klassedimensionen. Det skulle blandt andet medføre, at en typisk byklasse som funktionærerne med logitmetoden skulle få for få stemmer hos landpartier som de Radikale og Venstre. Denne bias vil uundgåeligt "smitte af " på andre klasseestimater for disse to partier, for eksempel vil de selvstændige (hvis udbredelse i 1971 havde en negativ korrelation med urbaniseringsdimensionen) dermed fa en for stor andel stemmer fra de Radikale og Venstre.

Glans er overrasket over, at økologiske estimationer af klassernes vælgeradfærd i Danmark 1920-79 præsenteres uden selvkritisk granskning. Til mit (om end lidt mangelfulde) forsvar vil jeg sige, at den pågældende artikel er skrevet, før Glans præsenterede sine længe ventede surveyresultater om klassernes vælgeradfærd i Danmark 1953-1988 (Glans, 1989). Grunden til, at jeg synes min artikel om klassernes adfærd er værd at bringe igen, er, at de ovenfor kommenterede skævheder bliver mindre, når man grupperer partierne $\mathrm{i}$ artiklens fem grupper. Endvidere vil jeg også tillade mig at gøre opmærksom på (siden Glans ikke finder det værd at nævne), at meget væsentlige hovedtendenser i Glans' resultater, såsom faldende socialdemokratisk tilslutning blandt arbejdere og selvstændige samt stigende tilslutning til venstrefløjen blandt funktionærer, genfindes i de $ø$ kologiske estimater.

Glans i rollen som "ligtornetramper " videreføres i hans kommentarer til Berglund og Wörlunds (1990) præsentation af vælgervandringer i Sverige 1985-88. Ganske vist er denne artikel ikke med i den aktuelle bog; men hans bemærkninger er alligevel relevante, da artiklen bygger på erfaringerne fra bogens validitetsanalyser af svenske vælgervandringer 1970-85. Berglund og Wörlunds artikel er nemlig det første forsøg på at foretage en landespecifik tilpasning af logitmetoden. Ud fra den konstatering, at den simple logitmetode i Sverige overestimerede vælgerstabiliteten i forhold til surveyresultater, havde vi som en simpel løsning (ret teoriløst) indført en deflationsfaktor, som nedsatte samtlige økologiske korrelationer med en fast procentdel. Dette giver en langt bedre tilpasning til surveyresultaterne 1970-85, så det er faktisk noget overraskende, at validiteten tilsyneladende er lavere for 1985-88. Med henvisning til diskussionen i starten af mit indlæg vil jeg ikke hæfte mig for meget ved de mange "signifikante" afvigelser, og jeg vil også beklage, at der i Sverige ikke findes alternativer til Göteborg Universitets "monopol " på landsdækkende vælgerundersøgelser.

En mulig forklaring på den tilsyneladende manglende validitet kan være, at bevægelserne for De Grønne spillede en særlig stor rolle ved det svenske valg i 1988. 
Det er faktisk et generelt fund fra flere lande, at logitmetoden er dårligere til at estimere vælgervandringer for issuebaserede partier, såsom miljøpartiet i Tyskland, Alliancen i UK og de Radikale i Danmark, end for andre mere strukturelt baserede partier. Forklaringen kan være, at det økologiske niveau dårligere afspejler den individuelle variation for issuepartier end for strukturelt baserede partier. Eksemplet illustrerer, at selv manglende validitet ved økologisk inferens kan have en vis faglig "brugsværdi«.

\section{Kommentarer til Hans Jorgen Nielsen}

Jeg har ikke så mange kommentarer til Hans Jørgen Nielsens indlæg, fordi jeg overvejende er enig i hans synspunkter. Hans simple firefeltstabel over mulige kombinationer af interview og økologisk forskning giver et fortrinligt overblik over den forskningsstrategiske situation.

Han har nok ret $i$, at vi i valideringskapitlet indtager et lidt for ydmygt standpunkt, når vi implicit hævder, at det er muligt at korrigere surveyresultater, så der kun er stikprøveusikkerhed tilbage. Jeg kommer til at tænke på, at det netop var et vigtigt fund ved det økologiske studium af historiske vælgervandringer i Danmark, at sofavælger"partiet « spillede en vigtig rolle som "stødpude" ved partiskift (Thomsen, 1987: 90-91).

Dog synes jeg, at Nielsen fortolker vore konklusioner lidt for hårdhændet, når han kalder vor selvkritik for destruktiv. Faktisk er pointen, at vi med den simple logitmetode nok har tabt det første slag, men til gengæld fảet erfaringer, som tyder på, at der er mulighed for at vinde et nyt ved videreudvikling af metoden.

Man kunne også påpege, at diskussionen føres lidt for snævert som et spørgsmål om for eller imod økologisk inferens, eventuelt om man også skal inddrage $ø$ kologiske variabler i interviewundersøgelser. Halvdelen af bogen omhandler jo økologisk makroanalyse, hvor man ikke forsøger økologisk inferens. Økologisk makroanalyse er særlig anvendelig over for fænomener, som er stærkt præget af specifikke lokale forhold. Oplagte emner er den geografiske spredning af nye bevægelser og samspillet mellem national og lokal politik.

\section{Afsluttende bemærkninger}

Det er et åbent spørgsmål, om det nogensinde bliver muligt at udvikle en metode til økologisk inferens, som giver så valide resultater, at de kan konkurrere alvorligt med surveyundersøgelser. På trods af dette mener jeg alligevel, at der her er tale om et virkelig godt samfundsvidenskabeligt problem.

For det første påpeger problemet nødvendigheden af at opstille relevante og præcise adfærdsmodeller for sável individuel som aggregeret adfærd samt for forholdet mellem disse to niveauer. For det andet har problemet - på trods af alt det ondskabsfulde man kan finde på at sige om interviewundersøgelser - et særdeles håndfast verificerings- og falsificeringskriterium i surveyresultater. Endelig for det tredje giver en blot nogenlunde vellykket inferensmetode adgang til en guldgrube af ny viden især om historiske forhold. Alle tre forhold gør det spændende at arbejde med økologisk inferens - også selv om der er mange, der står og griner ved sidelinjen. 


\section{Noter}

1. Årsberetning 1990 fra Institut for Statskundskab, Aarhus Universitet, giver en kort introduktion til de enkelte kapitler i bogen.

2. Noget som typisk medvirker til signifikante afvigelser mellem inferensestimat (som population) og surveyresultat (som stikprøve) er, at inferensmetoder ofte giver en del tabelceller med overgangssandsynligheder lig med eller tæt ved nul. Bergs forslag om at gruppere diagonalceller giver større robusthed over for dette fænomen.

3. Jeg har dog et forslag, som bygger på en signifikansbetragtning. Forslaget går ud på, at man betragter inferenstabellen ikke som en population, men som en stikprøve af ukendt størrelse. Man beregner derefter, hvor stor denne stikprøve skulle være for lige netop ikke at give en signifikant forskel i forhold til en tabel fra en surveyundersøgelse (for eksempel med en Chi-square test). Hvis dette tal er af samme størrelsesorden som en rimelig stor stikprøve, for eksempel på 1000 personer, accepteres inferensestimatet som noget, der kan konkurrere med surveyresultater.

4. Jeg vil ikke påstå, at denne invarians mellem separate regioner er en test på logitmetodens validitet, men blot påpege, at metoden på en invariant måde kan opfange systematik i de økologiske data. Dette give håb om en gunstig videreudvikling af metoden.

5. For valgkredsdata er indekset for forskellen mellem survey og inferens for hver af de fire metoder: Thomsen: 10.6, Kohlsche: 16.9, Krauss: 21.1, Swindel, 33.8. For valgstedsdata: Thomsen: 7.9, Kohlsche 11.5, Krauss: 16.0, Swindel: 20.9.

\section{Litteratur}

Berglund, Sten og Ingemar Wörlund (1990). The Disintegration of the Swedish Five-Party System or the Success of Small Parties on an Increasingly Oligopolistic Market, paper prepared for presentation at the Nordic Political Science Conference in Reykjavik.

Glans, Ingemar (1989). "Langtidsudviklingen i dansk vælgeradfærd" pp. 52-83 i J. Elklit og O. Tonsgaard (red.), To Folketingsvalg, Århus: Politica.

Kohlsche, Andreas (1991). Estimation of Voting Migration and Vote Splitting, München: Gesellschaft für Datenverarbeitung und Statistik.

Krauss, Fritz (1991). Comparison of the Results of Different Ecological Models concerning Voting Transitions in the Federal Elections (Bundestagswahl) 1990, paper for the workshop on "Analysing Voting Behaviour Using Election Results" at the ECPR Joint Sessions of Workshops, Essex, March 22-28.

Nannestad, Peter (1989). Reactive Voting in Danish General Elections 1971-1979, Aarhus University Press.

Thomsen, Søren Risbjerg (1972). "Models for Change in Voting Behavior ", Scandinavian Political Studies, vol. 7, pp. 177-189.

Thomsen, Søren Risbjerg (1987). Danish Elections 1920-79, Århus: Politica. 